\title{
Strike-induced chemosensory searching in Old World vipers and New World pit vipers
}

\author{
DAVID CHISZAR \\ University of Colorado, Boulder, Colorado \\ CLAES ANDREN and GÖRAN NILSON \\ University of Göteborg, Göteborg, Sweden
}

BARBARA O'CONNELL, JOSEPH S. MESTAS, JR., and HOBART M. SMITH

University of Colorado, Boulder, Colorado

and

CHARLES W. RADCLIFFE

Denver Zoological Gardens, Denver, Colorado

\begin{abstract}
It is known that striking rodent prey induces a sustained, high rate of tongue flicking in rattlesnakes. The present study shows this phenomenon (called strike-induced chemosensory searching, SICS) to occur in species of rattlesnakes not previously investigated and in two species of Agkistrodon. SICS occurs in Old World vipers (Eristocophis, Vipera, Bitis), including species which normally hold their prey after striking. A hypothesis is offered which (1) accounts for the occurrence of SICS in these latter species and (2) suggests that SICS in some viperids may have arisen through paedomorphic evolution. More generally, it is concluded that SICS is probably a homologous trait in vipers and pit vipers and that the trait may have first appeared in elapid ancestors of the viperidae.
\end{abstract}

Rattlesnakes of most species typically strike and release adult rodent prey (Gans, 1966; Radcliffe, Chiszar, \& O'Connell, 1980), allowing the envenomated organisms (mice) to wander an average of $185 \mathrm{~cm}$ before they succumb to the effects of venom (Estep, Poole, Radcliffe, O'Connell, \& Chiszar, 1981). Although this predatory strategy risks losing the rodent, it also spares the snakes from tissue damage which could result from rodent teeth and claws if the snakes held the prey in their jaws after the envenomating strike. Rattlesnakes are able to detect chemicals associated with envenomated rodents (Chiszar, Duvall, Scudder, \& Radcliffe, 1980; Duvall, Chiszar, Trupiano, \& Radcliffe, 1978; Duvall, Scudder, $\&$ Chiszar, 1980) and to follow trails left by envenomated and nonenvenomated rodents (Baumann, 1927, 1928, 1929; Brock, 1980; Dullemeijer, 1961 Naulleau, 1965; Wiedemann, 1932; Golan, Radcliffe, Miller, O'Connell, \& Chiszar, Note 1; see Burghardt, 1970 , for a review). These abilities are presumed to facilitate location of the envenomated prey and,

D. Chiszar, B. O'Connell, and J. S. Mestas, Jr., are affiliated with the Department of Psychology, University of Colorado, Boulder, Colorado 80309. C. Andren and G. Nilson are affiliated with the Department of Zoology and H. M. Smith with the Department of E.P.O. Biology of their respective institutions. therefore, to minimize the risk of losing the prey as a consequence of releasing it.

Rattlesnakes exhibit high rates of tongue flicking after striking rodent prey. The tongue transfers molecules from the environment to the vomeronasal organs located in the roof of the snake's mouth (Halpern \& Kubie, 1980; Kahmann, 1932). This strike-induced chemosensory searching (SICS) is considered to be a modal action pattern (cf. Barlow, 1968, 1977) activated by the predatory strike; and, it is probably essential for efficient trailing (Chiszar, Radcliffe, O'Connell, \& Smith, 1980; Chiszar, Radcliffe, \& Scudder, 1977; Chiszar, Radcliffe, \& Smith, 1978; see Chiszar \& Scudder, 1980, for a review). Although rattlesnakes will emit relatively high rates of tongue flicking in the presence of certain visual and chemical cues derived from rodents, even without an opportunity to strike (Chiszar, Taylor, Radcliffe, \& Smith, 1981; Gillingham \& Baker, 1981; Gillingham $\&$ Clark, 1981), these rates are typically lower and habituate more rapidly than those seen during SICS. Hence, we suspect SICS to be a component of the usual reaction chain involved in rattlesnake predatory behavior (but it is not a prerequisite for all instances of feeding, especially when odoriferous carrion is available: Gillingham \& Baker, 1981).

Since rattlesnakes usually release adult rodents after striking them whereas some Old World vipers 
(especially Bitis) usually hold on, we have assumed that SICS and trailing behavior are characteristic adaptations of the former. There has been no reason to expect these behaviors to occur in snakes that hold on to their prey after the initial strike, but not all vipers hold on to their prey. The present experiments were designed to assess the magnitude of SICS in a variety of Old World vipers, including species that typically release and species that typically hold rodent prey. Several species of rattlesnakes not previously tested were also studied in order to document the generality of SICS within this group.

The family Viperidae is divided into three subfamilies: Viperinae (Old World vipers; 40 species), Crotalinae (pit vipers; 122 species; many confined to the New World), and Azemiopinae (containing a single species, Azemiops feae, from southeastern Asia). (Live specimens of $A$. feae are extremely rare in zoo and/or research collections, and their behavior is virtually unknown. Accordingly, $A$. feae will not be mentioned again in this report. See Liem, Marx, \& Rabb, 1971). Although SICS has been well documented among the Crotalinae (especially Crotalus, Sistrurus, and Agkistrodon; Chiszar \& Scudder, 1980), the phenomenon has not yet been demonstrated in any species of Viperinae. However, several reports strongly suggest that SICS occurs in these animals (especially in Vipera; Baumann, 1927, 1928, 1929). The present study was designed to assess this possibility not only in European Vipera, but also in African Bitis and Asian Eristocophis. Should SICS occur in all of these taxa, an argument which homologizes the phenomenon would be strengthened. Such data could imply that SICS was present in elapid ancestors presumed to have given rise to the earliest viperids 20-70 million years ago (Marx \& Rabb, 1965).

\section{METHOD}

\section{Subjects}

A total of 33 snakes were observed: Eristocophis macmahoni (2), Vipera raddei (3), V. xanthina (2), V. ammodytes (2), V. latifii (2), Bitis gabonica (2), B. arietans (2), Agkistrodon bilineatus (2), A. piscivorus (4), Crotalus adamanteus (2), C. durissus (1), C. horridus (2), C. molossus (1), C. pricei (2), C. scutulatus (1), C. triseriatus (2), and $C$. viridis (1). All animals were adults and had been maintained in captivity for at least 2 years, except for the B. gabonica, which were less than 6 months old at the time of this study. The snakes were maintained in individual glass terraria $(50 \times 27.5 \times 30 \mathrm{~cm})$ and kept at $26 \pm 1^{\circ} \mathrm{C}$ during photophase $(0700-1900 \mathrm{~h})$ and at $23 \pm 1^{\circ} \mathrm{C}$ during scotophase. Live mice (Mus musculus, $20 \mathrm{~g}$ ) were offered to each snake weekly, and these prey were readily accepted.

\section{Procedure}

Each snake was observed in two conditions, and observations always occurred prior to a regularly scheduled feeding session. In Condition NS (no strike), a live mouse $(20 \mathrm{~g})$ was suspended by the tail from long forceps and introduced into the snake's cage for $3 \mathrm{sec}$. The mouse was held just out of striking range (about $30 \mathrm{~cm}$ from the snake's head); and, if the snake moved toward the mouse, the prey was moved to keep it out of striking range. In no case did a snake attempt to strike during an NS presentation, although snakes almost always oriented and/or moved toward the prey. Following the 3-sec presentation, the mouse was removed, the snake's cage was closed, and all tongue flicks were recorded (via hand-held counters) for the next $15 \mathrm{~min}$. In Condition S (strike), a mouse was introduced exactly as above, except that the snake was allowed to strike this prey at the end of $3 \mathrm{sec}$. After the prey was released, it was removed and tongue flicks were recorded as described above. If the prey was not released, forceps were gently applied to the snake's neck while the rodent's tail was gently pulled with another set of forceps. This procedure was continued until the snake released the mouse; then tongue flicks were counted for the next $15 \mathrm{~min}$. This treatment was required for $B$. Gabonica and E. macmahoni on about half of the S trials and for $B$. arietans on all S trials. Generally, SICS was stronger on trials when prey was spontaneously released than when coaxing was necessary, reflecting the fact that such handling disturbed the snakes at least temporarily (Chiszar, Radcliffe, O'Connell, \& Smith, 1981; O'Connell, Chiszar, \& Smith, 1981). Hence, the magnitude of SICS was probably underestimated in these species.

Tongue flicks were also recorded for $5 \mathrm{~min}$ prior to each NS and $S$ observation. These baseline data were used to assess the excitatory effects of both types of mouse presentation.

Most snakes were observed once per week, and the order of the NS and S presentations was randomized. When snakes were observed more than once per week, the NS condition always preceded the $\mathrm{S}$ condition by at least $1 \mathrm{~h}$. If a habituation effect occurred, Condition $\mathrm{S}$ should have produced lower scores than Condition NS.

\section{RESULTS}

Since each snake was observed in Conditions NS and $\mathrm{S}$, this variable was treated as a repeated-measures factor in analyses of variance (ANOVAs). Successive post-mouse-presentation minutes were also treated as

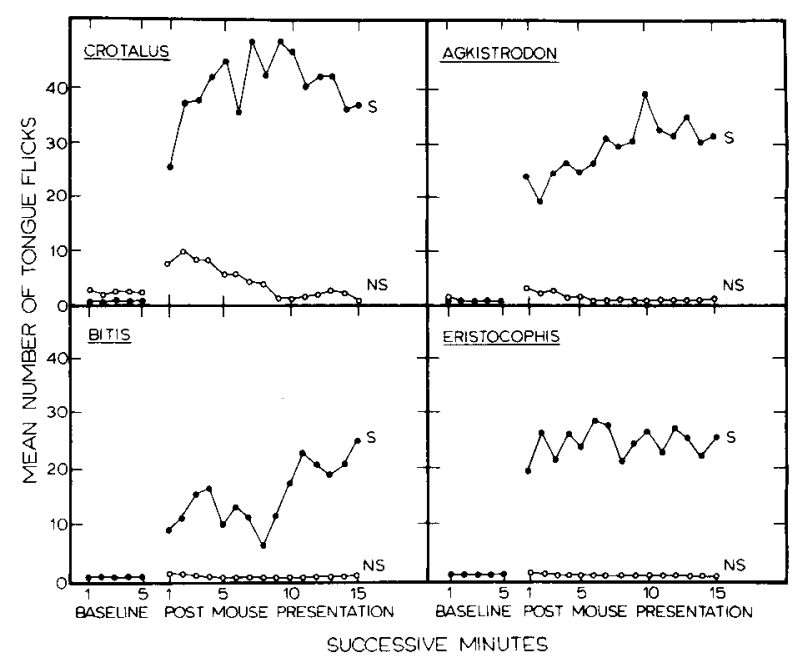

Figure 1. Mean number of tongue flicks emitted by specimens of four genera of venomous snakes over 5 min prior to disturbance and over $15 \mathrm{~min}$ beginning immediately after mouse presentations. In Condition NS, snakes saw, smelled, and/or detected thermal cues arising from a mouse for 3 sec. Condition $S$ was exactly like Condition NS except that snakes struck mice at the end of 3 sec. See Table 1 for number of specimens and statistical tests. Homogeneity of variance existed within each genus over post-mousepresentation minutes (Ferguson's, 1976, test of correlated variances was applied to the data). Pooled SEMs $=3.68,2.89,5.43$, and 2.71 for Crotalus, Agkistrodon, Bitis, and Eristocophis, respectively. 


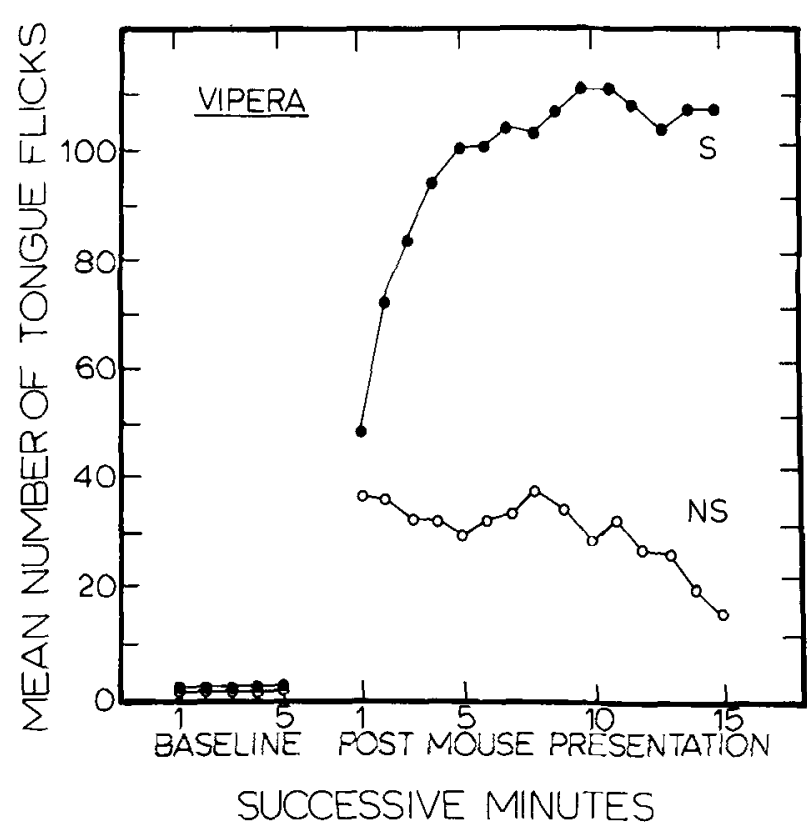

Figure 2. Mean number of tongue flicks emitted by nine specimens of Vipera over $5 \mathrm{~min}$ prior to disturbance and over $15 \mathrm{~min}$ beginning immediately after mouse presentation. Conditions NS and $S$ are the same as described in Figure 1 . See Table 1 for statistical tests. Homogeneity of variance existed over post-mousepresentation minutes (Ferguson's, 1976, test of correlated variances was applied). Pooled SEM $=4.14$.

a repeated-measures factor. Data were grouped by genus, and separate $2 \times 15$ ANOVAs were calculated for each genus. Some snakes were observed two or three times in Conditions NS and S. In these cases, data were averaged over replications, and these averages were used in the ANOVAs. All analyses were planned to test the significance of the NS vs. S effect and the NS vs. $\mathrm{S} \times$ minutes interaction; no comparisons of taxa were planned, but several post-hoc tests were executed.

Mean rates of tongue flicking for each genus are plotted over successive minutes for Conditions NS and $S$ in Figures 1 and 2. The results of ANOVAs are shown in Table 1, in which it can be seen that the NS vs. S effect was robust in all genera. It has been a characteristic finding with rattlesnakes that the NS vs. S difference is relatively small during Minutes 1-3 poststrike, and that the $S$ curve then rises, whereas the NS curve declines to the baseline level (Chiszar et al., 1977, 1978). This finding occurred again in the present sample of rattlesnakes and in two other genera (Agkistrodon and Vipera), giving rise to significant interactions between successive minutes and the NS vs. S factor (see Table 1; see also Chiszar, Simonsen, Radcliffe, \& Smith, 1979). The numerical interaction present in the Bitis data did not attain statistical significance. The Eristocophis sample is too small to permit any powerful tests.

One surprising outcome of this investigation was the very high rates of tongue flicking exhibited by all specimens of Vipera (Figure 2). One-way ANOVAs confirmed that these animals had significantly higher rates than all other snakes in Condition NS $[F(1,31)$ $=51.47, \mathrm{p}<.01]$ as well as in Condition $\mathrm{S}[\mathrm{F}(1,31)$ $=61.01, \mathrm{p}<.01 \mathrm{j}$. Indeed, the rates recorded here are the highest of any snakes we have so far tested in more than 20 experiments. These high rates and the correspondingly large SICS effect seen in Vipera are probably related to the excellent trailing abilities reported for some species of this genus (Baumann, 1927, 1928, 1929; Naulleau, 1965; Wiedemann, 1932; see Burghardt, 1970, for a review).

\section{DISCUSSION}

It is clear that SICS occurred in Old World vipers, even in species that typically do not release rodent prey after striking (Eristocophis, Bitis). Hence, it is not appropriate to consider this phenomenon to be unique to the Crotalinae. In fact, SICS might be hypothesized to be a consequence of striking per se rather than an adaptation that facilitates trailing behavior. This idea is contraindicated by data demonstrating that SICS did not occur in rattlesnakes after defensive strikes whereas the same snakes did exhibit SICS after striking mice (O'Connell \& Chiszar, Note 2). Accordingly, its reasonable to conclude that SICS is adaptively associated with predatory behavior and is not simply a consequence of the act of striking. In all likelihood, a combination of chemical, tactile,

Table 1

Outcomes of ANOVAs Applied to Data Grouped by Genus

\begin{tabular}{|c|c|c|c|c|c|c|c|c|c|c|c|}
\hline \multirow[b]{3}{*}{ Genus } & \multirow{3}{*}{$\begin{array}{l}\text { Number of } \\
\text { Specimens }\end{array}$} & \multicolumn{6}{|c|}{ F Ratios } & \multicolumn{4}{|c|}{$\begin{array}{l}\text { Percentage of Variance } \\
\text { Accounted for }\end{array}$} \\
\hline & & \multicolumn{2}{|c|}{ NS vs. $S$} & \multicolumn{2}{|c|}{ Successive Min } & \multicolumn{2}{|c|}{ Interaction } & \multirow{2}{*}{$\begin{array}{l}\text { NS vs. } \\
\quad \mathrm{S}\end{array}$} & \multirow{2}{*}{$\begin{array}{l}\text { Succes- } \\
\text { sive Min }\end{array}$} & \multirow{2}{*}{$\begin{array}{l}\text { Inter- } \\
\text { action }\end{array}$} & \multirow[b]{2}{*}{$\Sigma$} \\
\hline & & $\mathrm{F}$ & $\mathrm{df}$ & F & $\mathrm{df}$ & $\mathrm{F}$ & df & & & & \\
\hline Crotalus & 12 & $26.82 \dagger$ & $1 / 11$ & 1.36 & $14 / 154$ & $2.24 \dagger$ & $14 / 154$ & 40.5 & 9 & 1.7 & 43.1 \\
\hline Agkistrodon & 6 & $22.58 \dagger$ & $1 / 5$ & 1.18 & $14 / 70$ & $2.13^{* *}$ & $14 / 70$ & 57.4 & 1.5 & 2.5 & 61.4 \\
\hline Bitis & 4 & $27.50^{\dagger}$ & $1 / 3$ & .41 & $14 / 42$ & .45 & $14 / 42$ & 38.1 & 3.2 & 3.5 & 44.8 \\
\hline Eristocophis & 2 & $32.05^{*}$ & $1 / 1$ & .35 & $14 / 14$ & .61 & $14 / 14$ & 87.5 & .9 & 1.2 & 89.6 \\
\hline Vipera & 9 & $167.73 \dagger$ & $1 / 8$ & 4.297 & $14 / 112$ & $10.88 \dagger$ & $14 / 112$ & 71.1 & 2.5 & 5.7 & 79.3 \\
\hline
\end{tabular}

${ }^{*} p<.25 . \quad{ }^{*} p<.05 . \quad t_{p}<.01$. 
and proprioceptive consequences of the predatory strike is the releaser for SICS which, in turn, subserves trailing behavior (Iglehart \& Chiszar, 1977; Golan et al., Note 1; Scudder, Note 3).

One compelling problem is to provide an explanation for the occurrence of SICS in Eristocophis and Bitis. The hypothesis here advanced is based mainly on observations of juvenile $B$. gabonica in this study, on observations of adults elsewhere, and on observations of cobras (see below). Adult $B$. gabonica have never been observed by us to release rodent prey; this is also true of adult $B$. arietans. However, the juvenile $B$. gabonica in this study occasionally released mice and then exhibited SICS and trailing behavior indistinguishable from that seen in rattlesnakes. It may be that the strike-release-trail strategy exists in Bitis as an adaptation by which neonates deal with relatively large and dangerous rodents. As the snakes attain adult size and strength, they appear to abandon this strategy in favor of holding the prey after striking. If this developmental sequence is representative of a relatively primitive condition in the evolution of venomous-snake predatory behavior, then it is tempting to speculate that Vipera, Crotalus, Sistrurus, and Agkistrodon have undergone a paedomorphic change by retaining into adulthood a behavioral trait which, in their ancestors, was restricted to the neonatal period. ${ }^{1}$

This speculation is weakened by the fact that so few juvenile $B$. gabonica have been observed. We have recently completed five experiments with juvenile cobras (Naja mossambica pallida, $\mathrm{n}=11$ ), which are well known for holding prey after striking, especially when the snakes are fully adult. These snakes exhibited SICS, and they regularly released rodents as a function of the size of the prey (Radcliffe, Stimac, Smith, \& Chiszar, 1982; Chiszar, Stimac, Poole, Miller, Radcliffe, \& Smith, Note 4). Such results support the above hypothesis and further suggest that the evolutionary events here proposed were initiated by elapid ancestors that gave rise to the Viperidae between the late Cretaceous and the mid-Miocene epochs, some 20-70 million years ago (Cope, 1896; Dowling, 1959; Johnson, 1956; Marx \& Rabb, 1965). Clearly, these ideas imply that SICS is homologous in the Elapidae and the Viperidae as well as in the Viperinae and Crotalinae.

The hypothesis of paedomorphic (neotenic) evolution of predation in advanced Viperinae and Crotalinae is attractive because it is consistent with certain aspects of morphology in these subfamilies (e.g., head size relative to body size; Klauber, 1956). Yet, other hypotheses could explain the behavioral findings reported here. For example, species that hold prey might have more potent venom than species which release prey and exhibit SICS and trailing behavior. Or the latter species may be smaller and possess less venom than the former. ${ }^{2}$ Hence, the strike-releasetrail strategy may be a consequence of body size and/or properties of the venom supply. Of course, neoteny in the advanced forms could explain reduced toxicity and body size, but such differences could have arisen for many other reasons. Accordingly, ideas about the evolution of viperid predatory strategies must be developed in association with data on ontogeny (Jimenez-Porras, 1964; Minton, 1967) and phylogeny (Brown, 1973; Minton, 1956, 1974) of venoms.

\section{REFERENCE NOTES}

1. Golan, L., Radcliffe, C. W., Millter, T., O'Connell, B., \& Chiszar, D. Trailing behavior in prairie rattlesnakes (Crotalus viridis). Manuscript submitted for publication.

2. O'Connell, B., \& Chiszar, D. Chemosensory searching after predatory and defensive strikes by rattlesnakes. Paper presented at the meeting of the Animal Behavior Society, Knoxville, Tennessee, June 22-26, 1981.

3. Scudder, K. M. Mechanisms mediating the sequential aspects of predatory episodes in crotalid snakes. Doctoral dissertation in preparation, University of Colorado, Department of E.P.O. Biology.

4. Chiszar, D., Stimac, K., Poole, T., Miller, T., Radcliffe, C. W., \& Smith, H. M. Strike-induced chemosensory searching in cobras (Naja naja kaouthia, N. mossambica pallida). Manuscript in preparation.

\section{REFERENCES}

Baumann, F. Experimente über den Geruchssinn der Viper. Revue Suisse de Zoologie, 1927, 34, 173-184.

BaumanN, F. Über der Bedeutung des bisses und des Geruchssinnes für den Nahrungserwerb den Viper. Revue Suisse de Zoologie, 1928, 35, 233-239.

BaumanN, F. Experimente über den Geruchssinn und der Beuterwerb der Viper (Vipera aspis L.). Zeitschrift für Vergleichende Physiologie, 1929, 10, 36-119.

Brock, O. G. Predatory behavior of eastern diamondback rattlesnakes (Crotalus adamanteus): Field enclosure and $Y$-maze laboratory studies, emphasizing prey trailing behavior. Unpublished doctoral dissertation, Florida State University, 1980.

Brown, J. H. Toxicology and pharmacology of venoms from poisonous snakes. Springfield, Ill: Thomas, 1973.

BurghardT, G. M. Chemical perception in reptiles. In J. W. Johnston, D. G. Moulton, \& A. Turk (Eds.), Communication by chemical signals. New York: Appleton-Century-Crofts, 1970.

Chiszar, D., Duvall, D., Scudder, K., \& Radcliffe, C. W. Simultaneous and successive discriminations between envenomated and nonenvenomated mice by rattlesnakes (Crotalus durissus and C. viridis). Behavioral and Neural Biology, 1980, 29, 518-521.

Chiszar, D., Radcliffe, C. W., \& O'Connell, B., \& Smith, H. M. Strike-induced chemosensory searching in rattlesnakes (Crotalus enyo) as a function of disturbance prior to presentation of prey. Transactions of the Kansas Academy of Sciences, $1980,83,230-234$.

Chiszar, D., Radcliffe, C. W., O'Connell, B., \& Smith, H. M. Strike-induced chemosensory searching in rattlesnakes (Crotalus viridis) as a function of disturbance prior to presentation of rodent prey. Psychological Record, 1981, 32, 57-62.

Chiszar, D., Radcliffe, C. W., \& Scudder, K. M. Analysis of the behavioral sequence emitted by rattlesnakes during feeding episodes. I. Striking and chemosensory searching. Behavioral Biology, 1977, 21, 418-425.

Chiszar, D., RadCliffe, C. W., \& Smith, H. M. Chemosensory searching for wounded prey by rattlesnakes is released by striking: A replication report. Herpetological Review, 1978, 9, 54-56. 
Chiszar, D. \& Scudder, K. M. In D. Müller-Schwarze \& R. M. Silverstein (Eds.), Chemical signals: Vertebrates and aquatic invertebrates. New York: Plenum Press, 1980.

Chiszar, D., Simonsen, L., Radcliffe, C., \& Smith, H. M. Rate of tongue flicking by cottonmouths (Agkistrodon piscivorous) during prolonged exposure to various food odors, and strike-induced chemosensory searching by the cantil (Agkistrodon bilineatus). Transactions of the Kansas Academy of Sciences, $1979,82,49-54$.

Chiszar, D., Taylor, S. V., Radchiffe, C. W., \& Smith, H. M. Effects of chemical and visual stimuli upon chemosensory searching by garter snakes and rattlesnakes. Journal of Herpetology, 1981, 15, 415-424.

Cope, E. D. The classification of the Ophidia. Transactions of the American Philosophical Society, 1896, 18, 186-219.

Dowling, H. G. Classification of the Serpentes: A critical review. Copeia, 1959, 38-52.

DullemeiJer, P. Some remarks on the feeding behavior of rattlesnakes. Koninklijke Nederlandische Academie van Wetenschappen, 1961, Series C, 64, 383-396.

Duvall, D., Chiszar, D., Trupiano, J., \& Radcliffe, C. W. Preference for envenomated rodent prey by rattlesnakes. Bulletin of the Psychonomic Society, 1978, 11, 7-8.

Duvall, D., Scudder, K. M., \& Chiszar, D. Rattlesnake predatory behavior: Mediation of prey discrimination, and release of swallowing by odors associated with envenomated mice. Animal Behaviour, 1980, 28, 674-683.

Estep, K., Poole, T., Radcliffe, C. W., O'Connell, B., \& Chiszar, D. Distance traveled by mice (Mus musculus) after envenomation by prairie rattlesnakes (Crotalus viridis). Bulletin of the Psychonomic Society, 1981, 18, 108-110.

Ferguson, G. S. Statistical analysis in psychology and education. New York: McGraw-Hill, 1976.

Gans, C. The biting behavior of solenoglyph snakes-its bearing on the pattern of envenomation. Proceedings of the International Symposium on Venomous Animals. Sao Paulo, Brazil: Instituto Butantan, 1966.

GillinghaM, J. C., \& Baker, R. R. Evidence of scavenging behavior in the western diamondback rattlesnake (Crotalus atrox). Zeitschrift für Tierpsychologie, 1981, 55, 217-227.

Gillingham, J. C., \& Clank, D. L. An analysis of prey searching behavior in the western diamondback rattlesnake, Crotalus atrox. Behavioral and Neural Biology, 1981, 32, 235-240.

Halpern, M., \& Kubie, J. L. Chemical access to the vomeronasal organs of garter snakes. Physiology \& Behavior, 1980, 24, 367. 371.

Iglehart, F., \& Chiszar, D. Covariation among elements of rattlesnake posture: Potential interspecific signals. Bulletin of the Psychonomic Society, 1977, 9, 294-296.

Jimenez-Porras, J. M. Intraspecific variations in composition of venom of the jumping viper, Bothrops nummifer. Toxicon, 1964, 2, 187-195.

Johnson, R. G. The origin and evolution of the venomous snakes. Evolution, 1956, 10, 56-65.

Kaнmann, H. Sinnesphysiologische Studien an Reptilien-I. Experimentalle Untersuchungen über das Jacobsonische Organ der Eidechsen und Schlangen. Zoologische Jahrbücher, Abteilung für Allgemeine Zoologie und Physiologie der Tiere, 1932, 51, 173-238.
KLAUBER, L. M. Rattlesnakes (2 vols.). Berkeley: University of California Press, 1956.

Liem, K. F., MARx, H., \& RABb, G. B. The viperid snake Azemiops: Its comparative cephalic anatomy and phylogenetic position in relation to Viperinae and Crotalinae. FieldianaZoology, 1971, 59, 65-126.

Marx, H., \& RABB, G. B. Relationships and zoogeography of the viperine snakes (family Viperidae). Fieldiana-Zoology, 1965, 44, 161-206.

Minton, S. A. Some properties of North American pit viper venoms and their correlation with phylogeny. In E. E. Buckley \& N. Porges (Eds.), Venoms (Publication No. 44). Washington, D.C: American Association for the Advancement of Science, 1956, 145-151.

Minton, S. A. Observations on toxicity and antigenic makeup of venoms from juvenile snakes. In F. E. Russell \& P. R. Saunders (Eds.), Animal toxins. New York: Pergamon Press, 1967.

Minton, S. A. Venom diseases. Springfield, Ill: Thomas, 1974. Naulleau, G. La biologie et le comportement predateur de Vipera aspis au laboratoire et dans la nature. Bulletin Biologique de la France et de la Belgique, 1965, 99, 395-524.

O'Connell, B., Chiszar, D., \& SMith, H. M. Effect of poststrike disturbance on strike-induced chemosensory searching in the prairie rattlesnake (Crotalus v. viridis). Behavioral and Neural Biology, 1981, 32, 343-349.

Radcliffe, C. W., Chiszar, D., \& O'Connell, B. Effects of prey size on post-strike behavior in rattlesnakes (Crotalus durissus, C. enyo, and C. viridis). Bulletin of the Psychonomic Society, 1980, 16, 449-450.

Radcliffe, C. W., Stimac, K., Smith, H. M., \& Chiszar, D. Effects of prey-size on post-strike behavior of juvenile red spitting cobras (Naja mossambica pallida). Transactions of the Kansas Academy of Science, 1982, in press.

Wiedemann, E. Zur biologie der Nahrunge-aufnahme der Kreuzotter, Vipera berus L. Zoologischer Anzeiger, 1932, 97, 278-286.

\section{NOTES}

1. It is noteworthy that species of Crotalinae that attain large adult size also tend to hold rodent prey after striking (e.g., C. atrox, $C$. durissus, $A$. piscivorus). This may reflect either a reversion to the primitive condition or a polyethic adaptation to a prey supply containing organisms that differ in size (Radcliffe et al., 1980). In either case, the strike-hold strategy seen in adult Bitis also occurs in some Crotalinae, even though the modal pattern for this subfamily appears to be strike-release-trail.

2. To initiate an analysis of this problem, venom toxicity data compiled by Brown (1973) were examined. Average mouse-LD $D_{s o}$ (mg/kg; IV) for the species in the present study which exhibit the strike-release-trail strategy was 1.41 ; the mean for species exhibiting the strike-hold strategy was $1.49(\mathrm{~F}<1.0)$. Average venom yield (dried solids) for the former species was $110 \mathrm{mg}$, whereas the mean for the latter species was $533 \mathrm{mg}[\mathrm{F}(1,13)=23.36$, $\mathrm{p}<.01)$.

(Manuscript received July 8, 1981; revision accepted for publication November 10, 1981.) 